\title{
Do Industrial Agglomeration and Investment Shrink Regional Inequality?
}

Farida Rahmawati ${ }^{1}$, Fitriani Romziatin ${ }^{1}$

${ }_{1}^{1}$ Faculty of Economics, Universitas Negeri Malang, Indonesia

Article Info

\section{Article history:}

Received: 20 March 2020;

Accepted: 22 July 2020;

Published: 01 October 2020.

Keywords: Economic growth; Industrial agglomeration;

Investment.

\section{Abstract}

An ideal economy that is enhancing the welfare of society is the primary goal of a Nation. However, prosperity and economic development are distributed adequately in each region as well as in East Java. Some regions could develop faster instead of other regions that lead to a disparity between regions in the regency/city of East Java Province. For this reason, this research comprehensively aims to analyse how the impact of industrial agglomeration and regional inequality in East Java. In addition, this study also involves other variables, namely investment and economic growth. The data of the study were obtained from Statistics Indonesia and the Investment Office of East Java during the period 2014 to 2018. The findings indicate that agglomeration provides a key role in inequality in the East Java region. Furthermore, investment has a negative influence on regional inequality, while economic growth positively influences regional inequality in East Java.

\section{How to Cite:}

Rahmawati, F., \& Romziatin, F. (2020). Do Industrial Agglomeration and Investment Shrink Regional Inequality? Jurnal Pendidikan Ekonomi \& Bisnis, 7(2), 101-111. https://doi.org/10.21009/JPEB.008.2.4

* Corresponding Author.

farida.rahmawati,fe@um.ac.id. Farida Rahmawati
ISSN

2302-2663 (online)

DOI: doi.org/10.21009/JPEB.008.2.4 


\section{INTRODUCTION}

The economic development has primary roles in promoting the income per capita and enhancing productivity. The increase in total income and income per capita that marks economic growth is broadly shown by the Gross Domestic Product (GDP) and Gross Regional Domestic Product (GRDP) for the nation and regional, respectively. Therefore, economic development is closely related to economic growth. Economic development encourages economic growth, while economic growth facilitates the process of economic development (Meyer et al., 2017). Also, the leading indicators of economic development are depicted by economic growth, incomes equality, and poverty alleviation (Lin, 2003; Goh et al., 2009; Fosu, 2017; Rachmawati et al., 2018; Wulandari et al., 2019)

Each region has different capabilities and resources that lead to diverse economic growth. Regional economic growth can also be caused by the differences in leading regional sectors (Kharisma \& Hardiyanto, 2019; Mardalena et al., 2019). In East Java, for instance, it has industrial sectors in providing significant contributors to the provincial GRDP. The development of industry in East Java spreads out in several cities that make it indirectly created a center in the industrial sector-industrial agglomeration. Agglomeration is a concentration of both economic activities and a spatial population that results in savings due to its proximity (Guliano et al., 2019, Puga, 2010, Kuncoro, 2011)

The principles of cost-minimize commonly generate the determination of industrial location. Lapinskaite and Kuckailyte (2014) added that the location for each industry depends on the total transportation and labor costs, where the sum of the two must be a minimum. If the location of the industry is located in an area close to the factors of production (labor, capital) as well as the current distribution of goods to the market, it will provide benefits in the form of lower costs that must be incurred by an industry. The concentration of the industrial sector in a region will have an impact on increasing income per capita from the people (Harun, 2017). Thus, it is expected that regional income, which is included in the industrial agglomeration area, is more excellent than in other regions.

On the other hand, Arsyad (2004) noted revealed that a negative impact on the economic expansion the income inequality. This is due to the reason that the economic activities solely focus on a particular location rather than other locations. An economic expansion which concentrated in a particular area will harm other regions due to the existing labor, capital, the trade will move to the area that is expanding so that other regions will lack productive labor and capital. As a result, regions face that lack these resources will develop inadequately. Besides having an impact in increasing regional income and income per capita of the community, the industrial development potentially promotes a new investment. In this case, it allows investment by the private sector, government, foreign, and domestic

Investment in an area provides higher productivity in the surrounding community. It can be seen by community involvement, which will result in inclining income per capita and alleviating unemployment. However, in providing a new investment in a region, investors will consider several factors such as geographical conditions, natural resources, and demographics (Dunford et al., 2014; Jain \& Ranawat, 2012; Mittal \& Vyas, 2007). In fact, the circumstances in the regions in East Java are different between geography and demographics. This condition caused investments made by the government, and the private sector are not spread evenly solely concentrated in a few certain regions. These issues will lead to diverse income per community, infrastructure, and economic development between regions.

Inevitable previous studies on the investment, economic growth, and income inequality have examined by scholars (Chen \& Fleisher, 1996; Tian et al., 2016; Lestari \& Gunawan, 2017; Kurniasih, 2017; Rachmawati et al., 2018; Bonet, 2006; Ge, 2006), while few number studies which elaborated industrial agglomeration in predicting income disparity in a region or nation (Xie et al., 
2012). For Instance, Xie et al. (2012) and Ge (2006) demonstrated a correlation between industrial and income disparity in China. The finding showed that by improving the level of agglomeration, it would narrow the income inequality in a particular area in the country. In fact, minor attention of scholars in involving the industrial agglomeration and income disparity particularly in East Java (Wahyuntari \& Pujiati, 2016; Islami \& Nugroho, 2018; Istiqamah et al., 2018)

The data from Statistics Indonesia (2019) noted a high inequality level in East Java Province. From the data, it is provided that the urban area is more dominated by the industrial sector, while the rural area is the agricultural agriculture sector. The productivity of the people of these two regions that is certainly different, which results in the income per capita of the community obtained from the people in the rural area, is smaller when compared to more urban areas. For these reasons, this study provides insights on shrink income inequality by elaborating on several variables, including industrial agglomeration, investment, and economic growth.

\section{METHOD}

This study applied a quantitative method using a descriptive research approach. This method is particularly useful in understanding the relationship between variables comprehensively. This study used secondary data from 2014 to 2018 from various sources such as Indonesia Statistics and Investment Agency of East Java. We applied a Balassa index to measure industrial agglomeration (Sbergami, 2002). Also, the data for both domestic investment and foreign investment were expressed in the form of dummy variables; this is due to not evenly distributed for each region even in some districts there is no incoming investment. For economic growth, we applied data for GDP per capita, while regional inequality is illustrated by the Williamson index of each district/city in East Java. The Williamson index value ranges from 0 to 1 , where the value approaches 0 , development is evenly distributed, whereas when approaching 1 , the development between regions is very lame (Sjafrizal, 2018).

Furthermore, the data were analyzed using multiple linear regression data panel by engaging Eviews 8. In addition, to choose the fit model to use, a chow test, a Hausman test, and a multiplier Lagrange test are performed. A chow test was performed to choose between the Common Effect Model (CEM) or the Fixed Effect Model (FEM). Hausman test was done to choose between Fixed Effect Model (FEM) or Random Effect Model (REM), whereas the Lagrange multiplier test was applied to choose between Random Effect Model (REM) or Common Effect Model (CEM). In addition to the selection of a regression model also requires a classic assumption test to determine whether or not the variables used in this study are feasible. In this study, the significance test was also carried out in the form of t-test and f-test. T-test was conducted to determine the effect of each independent variable on the dependent variable, while F-test was used to determine the effect of all the independent variables on the dependent variable together. In more detail, the econometrics model used is illustrated in the following formula.

$$
\begin{gathered}
Y=\beta_{0}+\beta_{1} X_{1}+\beta_{2} X_{2}+\beta_{3} X_{3}+\mu \\
K R=\beta_{0}+\beta_{1} A G L_{i t}+\beta_{2} I N V_{i t}+\beta_{3} P E_{i t}+\mu
\end{gathered}
$$

Where :

$$
\begin{array}{ll}
Y & =\text { Regional Inequality } \\
X_{1} & =\text { Industrial Agglomeration } \\
X_{2} & =\text { Investment } \\
X_{3} & =\text { Economic Growth } \\
\beta_{0} \beta_{1} \beta_{2} \beta_{3} & =\text { coefficient of independent variable } \\
\mu & =\text { Error of term }
\end{array}
$$




$$
\begin{array}{ll}
i & =\text { Subject } \\
t & =\text { Time period }
\end{array}
$$

\section{RESULTS AND DISCUSSION}

To determine a model fit, this study performed by the Chow Test and the Hausman Test, the Lagrange Multiplier Test, was not conducted due to the two prior tests was known that the best model was to use the Fixed Effect Model (FEM). Table 1 and Table 2 inform the determination of the regression model using both tests. From the tables, it is known that the probability of the Chow test and Hausman test in respect is 0.0000 and 0.0183 . It implies that the fit model of this study is the Fixed Effect Model (FEM). In addition, the classic assumption test conducted in this study is the multicollinearity and heteroscedasticity test (see table 3).

Table 1. The determination of Regression Model Using Chow Test

\begin{tabular}{llll}
\hline \multicolumn{1}{c}{ Effects Test } & \multicolumn{1}{c}{ Statistic } & \multicolumn{1}{c}{ d.f. } & \multicolumn{1}{c}{ Prob. } \\
\hline Cross-section F & 89.726106 & $(37,149)$ & 0.0000 \\
Cross-section Chi-square & 598.050970 & 37 & 0.0000 \\
\hline
\end{tabular}

Table 2. The determination of Regression Model Hausman Test

\begin{tabular}{lccc}
\hline Test Summary & Chi-Sq. Statistic & Chi-Sq. d.f. & Prob. \\
\hline Cross-section random & 10.029578 & 3 & 0.0183 \\
\hline
\end{tabular}

Table 3. The Result of Multicollinearity test

\begin{tabular}{cccc}
\hline & LN_AGL & DM_INV & LN_PE \\
\hline LN_AGL & 1.000000 & 0.199335 & 0.449303 \\
DM_INV & 0.199335 & 1.000000 & 0.174297 \\
LN_PE & 0.449303 & 0.174297 & 1.000000 \\
\hline
\end{tabular}

From table 3, it can be seen that the result of multicollinearity test between variables is less than 0.8 , which means that the variables of this study satisfy the assumption. On the other hand, these variables failed in passing heteroscedasticity test. To address this issue, we conduct a weighting test by providing weighting to the variation of the data used which provided in table 4 .

Table 4.The Result of Regression FEM with Weighting

\begin{tabular}{crccr}
\hline \multicolumn{1}{c}{ Variable } & Coefficient & Std. Error & t-Statistic & \multicolumn{1}{c}{ Prob. } \\
\hline C & -4.546474 & 0.671369 & -6.771941 & 0.0000 \\
LN_AGL & 0.069812 & 0.013497 & 5.172479 & 0.0000 \\
DM_INV & -0.020041 & 0.009776 & -2.050016 & 0.0421 \\
LN_PE & 0.176060 & 0.065913 & 2.671081 & 0.0084 \\
R-squared & 0.997368 & Mean dependent var & -6.737050 \\
Adjusted R-squared & 0.996661 & S.D. dependent var & 4.258237 \\
S.E. of regression & 0.132612 & Sum squared resid & 2.620317 \\
F-statistic & 1411.508 & Durbin-Watson stat & 2.084981 \\
Prob(F-statistic) & 0.000000 & & \\
\hline
\end{tabular}

Table 4 provides the result of regression test using Fixed Effect Model. Based on the table, it is known that both partially and simultaneously industrial agglomeration, investment and economic growth significantly affects regional inequality. In more specific, the following equation present the 
relationship between variables.

$\mathrm{KR}=-4.546474+0.069812 \mathrm{LN}$ AGL $+(-0.020041) \mathrm{DM} \mathrm{INV}+0.176060 \mathrm{LN} \mathrm{PE}$

The value of R-squared from FEM after weighting is 0.9973 or 99.73 percent. Therefore, it can be concluded that the variable of regional inequality Regional $(\mathrm{Y})$ can be explained by Industrial Agglomeration $\left(\mathrm{X}_{1}\right)$, Investment $\left(\mathrm{X}_{2}\right)$, and economic growth $\left(\mathrm{X}_{3}\right)$. Moreover, it is known that the probability value of industrial agglomeration is 0.0000 with a positive sign. It implies that when industrial agglomeration has increased by 1 unit, it will increase regional inequality by 0.069812 units. In addition, the investment variable obtained a probability value of 0.0421 and has a negative coefficient. Therefore, when investment increases, regional inequality will decrease by 0.02004 . For economic growth variables, the probability value obtained is 0.0084 and has a positive coefficient value. Thus, when economic growth increases by 1 unit, it will increase regional inequality by 0.176060 units. Based on table 4, it is also known that the probability value of the F-statistic is 0.000000. It implies that all independent variables, namely industrial agglomeration, investment, and economic growth, have a significant effect on regional inequality.

\section{Industrial Agglomeration and Regional Inequality}

The first question in this study sought to determine the relationship between Agglomeration and Regional Disparity. This result supports previous researchers by Bonet (2006); Wahyuntari and Pujiati (2016); Ge, 2006), mentioning a significant influence between industrial agglomeration and regional inequality. Bonet (2006) pointed out that agglomeration can directly cause inequality when there are no barriers to labor migration between regions or when there is a surplus of labor in the economy. Similarly, Wahyuntari and Pujiati (2016) found that the industrial agglomeration had an effect on regional development disparities, regional economic growth would tend to be faster in regions with economic concentration. Ge (2006) added that industrial agglomeration contributes to increasing regional inequality by enhancing the gap in community productivity. The existence of industrial agglomeration produces positive externalities and increases local productivity in the region. In addition to increasing productivity, the existence of industrial agglomeration also encourages employment growth and wage disparity. The existence of this wage disparity is encouraging people to urbanize from non-agglomerated areas to agglomerated areas to obtain better welfare.

In the industrial agglomeration process, there are several important factors for selected areas. Ellison et al. (2010) revealed that agglomeration efficiency comes from a reduction in transportation costs. The transportation costs are in the form of the cost of the mobility of goods, labour, and ideas. In addition, determining location is based on the closer to greater market demand (Krugman, 1991), and the industrial area generally develops in areas that have easier distribution access to markets. The industrial agglomeration in East Java locates in several large cities and regencies which are located close to one another.

In more specific, the location of industrial agglomeration pointed in the areas with economic concentrations have high GRDP. This is due to the economic structure that concentrates on industry allows higher regional productivity when compared to rural areas or concentrated on agriculture. Furthermore, this will have an impact on the higher per capita income of the community as well. However, some other areas in East Java still concentrate on the agricultural or non-agglomeration sectors, where community productivity is lower than per capita income than the industrial area. Therefore, between these two regions, there is an inequality due to different economic concentrations. 


\section{Investment and Its Impact on Regional Inequality}

Investment plays a crucial role in affecting equality development and growth within regions (Sjafrizal, 2018). Areas that have high levels of investment and natural abundance can promote rapid growth. Basu and Guarglia (2007); Asongu (2013) revealed that investment would cause inequality due to not all districts/cities are targeted for investment. The existing condition of East Java has diverse resources owned by each region, including the economic sector. A well-developed economy will be able to increase growth and better regional income.

The finding of this study is relevant to a prior study by Islami and Nugroho (2018), which revealed that investment had a negative and significant effect on inequality. It implies that an investment will be able to reduce inequality between regions. A region with good economic development will encourage an increase in income and demand, which in turn will increase investment. Similarly, this study also supports a prior study by Fan et al. (2004), which stated that all types of investment in western China were the most developed in reducing regional imbalances.

\section{The Influence of Economic Growth and Regional Inequality}

The result of this study agrees with some previous studies which showed a relationship between economic growth and regional inequality. For instance, Li et al. (2016) prove that at the beginning of development or before the reformation in China, the disparity between provinces was quite high, which then declined since 2004 or after China reformed and opened up. Indeed, Istiqamah et al. (2018), economic growth has a significant and positive effect on regional income inequality. Economic growth is, in fact, felt by some population groups while other population groups have a stagnant economic level not only in rural areas but also in cities. Similar results showed by Iswanto (2015) confirming that increasing economic growth is accompanied by increasing inequality. This can be seen from the situation between regencies and cities in East Java, where several areas of construction of public infrastructure and the level of income per capita and labour costs are higher compared to other districts and cities.

The relationship between growth and regional inequality is expressed by the Neo-Classical theory about inequality in development, which was later proven by Williamson (Sjafrizal, 2018). Based on this evidence, it can be concluded that in the stages of national growth and development, there is a systematic relationship between the level of national development and regional inequality. Where inequality is highest in the initial stages of growth, then equality will be more consistent when it is at a more mature level of growth. Associated with this regional imbalance Walsh and Whelan (2010), states about the existence of unbalanced economic growth, namely that the transmission of economic growth between regions is also not smooth, then it tends to lead to areas that grow fast and slow-growing regions.

\section{CONCLUSIONS AND SUGGESTION}

This study examined the relationship between industrial agglomeration, investment, economic growth and regional inequality. Based on the previous discussion, it can be concluded that agglomeration provides a key role in inequality in the East Java region. Furthermore, investment has a negative influence on regional inequality, while economic growth positively influences regional inequality in East Java. There are several suggestions provided to the government include increasing community empowerment in the regions so that they are able to improve the community's economy both through leading sectors in the region. In addition, the development of small and medium industries will enhance community productivity.

The government is also expected to make policies that will later encourage investment into other areas in East Java, which not solely concentrated in a few regions. Besides increasing 
promotion for tourism, agriculture, and other sectors to be able to attract investors in other nonindustrial fields, the government needs to have superior potential in other potential sectors that can also develop.

\section{REFERENCES}

Adisasmita, R. (2008). Pengembangan Wilayah Konsep Dan Teori. Yogyakarta: Graha Ilmu.

Asongu, S. A. (2013). Investment and Inequality in Africa: which financial channels are good for the poor? African Finance Journal, 15(2), 43-65.

Basu, P., \& Guariglia, A. (2007). Foreign direct investment, inequality, and growth. Journal of Macroeconomics, 29(4), 824-839.

Bonet, J. (2006). Fiscal decentralization and regional income disparities: evidence from the Colombian experience. The Annals of Regional Science, 40(3), 661-676.

BPS. (2019). Jumlah Penduduk Miskin Jawa Timur. Retrieved from http://jatim.bps.go.id/subject/23/kemiskinan.html

Chen, J., \& Fleisher, B. M. (1996). Regional income inequality and economic growth in China. Journal of comparative economics, 22(2), 141-164.

Dunford, M., Liu, W., Liu, Z., \& Yeung, G. (2014). Geography, trade and regional development: the role of wage costs, exchange rates and currency/capital movements. Journal of Economic Geography, 14(6), 1175-1197.

Ellison, G., Glaeser, E. L., \& Kerr, W. R. (2010). What causes industry agglomeration? Evidence from coagglomeration patterns. American Economic Review, 100(3), 1195-1213.

Fan, S., Zhang, L., \& Zhang, X. (2004). Reforms, investment, and poverty in rural China. Economic Development and Cultural Change, 52(2), 395-421.

Fosu, A. K. (2017). Growth, inequality, and poverty reduction in developing countries: Recent global evidence. Research in Economics, 71(2), 306-336.

Ge, Y. (2006). The effect of foreign direct investment on the urban wage in China: An empirical examination. Urban Studies, 43(9), 1439-1450.

Giuliano, G., Kang, S., \& Yuan, Q. (2019). Agglomeration economies and evolving urban form. Ann Reg Sci 63, 377-398

Han, W., Zhang, Y., Cai, J., \& Ma, E. (2019). Does urban industrial agglomeration lead to the improvement of land use efficiency in China? An empirical study from a spatial perspective. Sustainability, 11(4), 986.

Harun, P. (2017). Structure changes, the contribution of sectors, income per capita Indonesia in 19902014. Journal of Economics, Business, \& Accountancy Ventura, 19(3), 293-304.

Islami, F. S., \& Nugroho, S. B. M. (2018). Faktor-faktor mempengaruhi ketimpangan wilayah di Provinsi Jawa Timur, Indonesia. Media Ekonomi dan Manajemen, 33(1), 29-39.

Istiqamah, I., Syaparuddin, S., \& Rahmadi, S. (2018). Pengaruh pertumbuhan ekonomi terhadap ketimpangan pendapatan dan kemiskinan (studi provinsi - provinsi di Indonesia). E-Jurnal Perspektif Ekonomi Dan Pembangunan Daerah, 7(3), 111 - 126.

Iswanto, D. (2015). Ketimpangan pendapatan antar kabupaten/kota dan pertumbuhan ekonomi di Propinsi Jawa Timur. Signifikan: Jurnal Ilmu Ekonomi, 4(1).

Jain, D., \& Ranawat, K. (2012). The Effect of Demographics on Investment Choice: An Empirical Study of Investors in Rajasthan. Journal of Management and Science, 2(2), 42-61.

Kharisma, B., \& Hadiyanto, F. (2019). Analysis of Potential Sectors and Policy Priorities of Regional Economic Development in Maluku Province. ETIKONOMI, 18(1), 29-46.

Krugman, P. (1991). Increasing returns and economic geography. Journal of political economy, 99(3), $483-499$.

Kuncoro, M. (2011). Perencanaan daerah bagaimana membangun ekonomi local, kota, dan kawasan. Jakarta: Salemba Empat. 
Kurniasih, E. P. (2017). Effect of economic growth on income inequality, labor absorption, and welfare. Economic Journal of Emerging Markets, 9(2), 181.

Lapinskaite, I., \& Kuckailyte, J. (2014). The impact of supply chain cost on the price of the final product. Business, Management and Education, 12(1), 109-126.

Lestari, S., \& Gunawan, R. S. (2017). Economic Growth and Income Disparity between Regencies/Cities in West Java Province. Eko-Regional: Jurnal Pembangunan Ekonomi Wilayah, 12(2).

Li, S., Wang, F., \& Xu, Z. (2016). The Trend of Regional Income Disparity in China. Working paper series, no. 193. Rimisp Santiago, Chile.

Lin, B. Q. (2003). Economic growth, income inequality, and poverty reduction in People's Republic of China. Asian development review, 20(2), 105-124.

Mardalena, M., Adji, A., Suhel, S., \& Andaiyani, S. (2019). How Leading Economic Sectors Stimulate Economic Growth, Income and Labor Absorption? Input-Output Approach. International Journal of Economics and Financial Issues, 9(1), 234.

Meyer, D. F., Masehla, T. M., \& Kot, S. (2017). The relationship between economic growth and economic development: A regional assessment in South Africa. Journal of Advanced Research in Law and Economics, 8(4 (26)), 1377-1385.

Mittal, M., \& Vyas, R. K. (2007). Demographics and investment choice among Indian investors. ICFAI Journal of Behavioural Finance, 4(2), 12-20.

Puga, D. (2010). The magnitude and causes of agglomeration economies. Journal of regional science, 50(1), 203-219.

Sbergami, F. (2002). Agglomeration and Economic Growth: Some Puzzles (No. BOOK). Graduate Institute of International Studies.

Sjafrizal. (2018). Analisis Ekonomi Regional dan Penerapannya di Indonesia. Depok: PT. Raja Grafindo Persada.

Rachmawati, A. M., Wulandari, D., \& Narmaditya, B. S. (2018). Financial Deepening and Income Inequality in Indonesia. Global Business Review, 0972150918811246.

Tian, X., Zhang, X., Zhou, Y., \& Yu, X. (2016). Regional income inequality in China revisited: A perspective from club convergence. Economic Modelling, 56, 50-58.

Wahyuntari, L. I., \& Pujiati, A. (2016). Disparitas pembangunan wilayah kabupaten/kota di Provinsi Jawa Tengah. Economics Development Analysis Journal, 5(3), 296-305.

Walsh, P. P., \& Whelan, C. (2010). Hirschman and Irish industrial policy. The Economic and Social Review, 41(3), 283.

Williamson, J. G. (1965). Regional inequality and the process of national development: a description of the patterns. Economic Development and Cultural Change, 13(4).

Wulandari, D., Narmaditya, B. S., Prayitno, P. H., Ishak, S., \& Asnan, L. (2019). Human Development Index, Poverty and Gross Regional Domestic Product: Evidence from Malang, Indonesia. Jurnal Pendidikan Ekonomi Dan Bisnis (JPEB), 7(2), 146-152.

Xie, L., Chen, Y., \& Kuang, X. M. (2012). Does Industrial Agglomeration Widen Regional Income Disparity? Evidence from Chinese Manufacture Industries. Economic Geography, (2), 3. 